\title{
Studying the in vivo microcirculatory adaptation to isometric contraction (dorsiflexion) in the human lower limb
}

\author{
Estudo sobre a adaptação microcirculatória in vivo à contração isométrica (flexão dorsal) no \\ membro inferior humano
}

\author{
Margarida Florindo ${ }^{1,2}$, Henrique Silva ${ }^{2,3}$, L. Monteiro Rodrigues ${ }^{2,3}$ \\ ${ }^{1}$ Department of Physiotherapy, Portuguese Red Cross Superior Health School, ESSCVP Lisboa, Portugal \\ ${ }^{2}$ CBIOS - Universidade Lusófona's Research Center for Biosciences and Health Technologies, Lisboa, Portugal \\ ${ }^{3}$ Pharmacol. Sc Depart — Universidade de Lisboa, Faculty of Pharmacy, Lisboa, Portugal \\ Email: mflorindo@esscvp.eu
}

\begin{abstract}
Blood flow in the lower extremities varies considerably due to changes in pressure from muscle contraction as occurs with calf muscle pump activity. The dorsiflexion is associated with functional walking performance, and its relation with microcirculation of lower limbs has not yet been addressed. In this study we explore the impact of dorsiflexion in the lower limb microcirculation with non-invasive technologies, as near as possible to the normal physiological state. Six (31 \pm 9 years) healthy subjects were enrolled in this study after informed written consent. The experimental protocol consisted of 5 minutes standing, 1 minute of dorsiflexor muscle group contraction, and 5 minutes recovery in the initial position. Microcirculation was evaluated by photoplethysmography (PPG) and laser Doppler flowmetry (LDF). Pulse rate (PR) was obtained from PPG. Nonparametric statistics were used for phase comparisons. Dorsiflexion significantly modified the local perfusion, with PPG registering a decrease $(\mathrm{p}=0.028)$ while LDF registered an increase $(\mathrm{p}=0.028)$. PR did not change during the procedure. Foot dorsiflexion seems to cause different responses in the skin microvascular networks which might be attributed to the different measuring depths of the techniques employed, justifying further studies.
\end{abstract}

Keywords: Microcirculation, dorsiflexion, PPG, LDF, standing

\section{Resumo}

O fluxo sanguíneo nas extremidades inferiores varia consideravelmente devido a mudanças de pressão causadas pela contração muscular, por exemplo da bomba muscular da região posterior da perna. A flexão dorsal está associada ao desempenho funcional da marcha e a relação com a microcirculação dos membros inferiores, ainda não foi abordada. Neste estudo, exploramos o impacto da flexão dorsal na microcirculação do membro inferior com tecnologias não invasivas, o mais próximo possível do estado fisiológico normal. Seis sujeitos saudáveis jovens (31 \pm 9 anos) participaram neste estudo após consentimento por escrito. O protocolo experimental consistiu em 5 min de pé, 1 min de contração dos flexores dorsais e 5 minutos de recuperação na posição inicial. A microcirculação foi avaliada por fotopletismografia (FPG) e pelo método de fluxometria por laser Doppler (FLD). A frequência de pulso (FP) foi obtida de FPG. Foram utilizadas estatísticas não paramétricas para a comparação entre as fases. A flexão dorsal modificou significativamente a perfusão local com a FPG a registar uma diminuição $(\mathrm{p}=0,028)$ enquanto o FLD registou um aumento significativo $(p=0,028)$. A FP não se alterou durante o protocolo. A flexão dorsal parece causar respostas diferentes nas redes microvasculares da pele, o que pode ser atribuído às diferentes profundidades de medição das técnicas utilizadas, o que justifica novos estudos.

Palavras-chave: Microcirculação, flexão dorsal, FPG, FLD, posição de pé 


\section{Introduction}

Laser Doppler flowmetry (LDF) and photoplethismography (PPG) have gained relevance as practical tools to assess microcirculation physiology ${ }^{[1-2]}$. These technologies, based in related biophysical principles, are simple to use, cause minimal discomfort, and provide assessments close to the normal local perfusion conditions. Nevertheless, these results should be carefully interpreted, considering the known difficulties recognized in these pulsatile signals ${ }^{[2]}$.

We are particularly interested in understanding the influence of local muscular activity in the microcirculatory adaptation to movement, a critical aspect of restoration of walking and a high priority for rehabilitation in some forms of stroke. The balance of microvascular dynamics is critical to understand the impact of muscle activity on the lower limb perfusion, and several studies have suggested that concentric plantar flexion changes local blood flow ${ }^{[3]}$. However, changes related with dorsiflexion activity have not been previously addressed. Many of our daily life activities take place in the stuprightanding position and involve walking ${ }^{[3-4]}$. At the lower limbs extremities, calf muscles play a fundamental role in local vascular structures due to the external pressure exerted on the vessel walls, and that includes microcirculation ${ }^{[5]}$. When walking, a regular alternation between contraction of plantarflexors and dorsiflexors takes place, which is reflected in cycles of contraction of antagonistic muscles. During dorsiflexion, there is a large decrease in the activity of the plantarflexors, which are considered the main calf muscular pump ${ }^{[3,5]}$. Additionally, the force required to perform plantarflexion is greater than for dorsiflexion, as it requires the ability to raise a larger weight against gravity. Weakness of the lower limb is associated with immobility or stasis, and these have been related to some cutaneous lesions, muscle pain and intermittent claudication due to peripheral circulation disease ${ }^{[6-7]}$. The impact of the antagonists of the calf muscle pump on addition (local) microcirculation remains incompletely defined, especially in the standing position. In this study we developed a methodology to assess microcirculation in vivo in the orthostatic position during the dorsiflexion by PPG and LDF measurements.

\section{Introdução}

A fluxometria por laser Doppler e a fotopletismografia ganharam relevância como ferramentas práticas para avaliar a fisiologia da microcirculação ${ }^{[1-2]}$. Estas tecnologias, baseadas em princípios biofísicos relacionados, são de simples utilização, causando um desconforto mínimo e permitem avaliações próximas das condições normais de perfusão local. No entanto, esses resultados devem ser cuidadosamente interpretados, considerando as dificuldades reconhecidas nestes sinais pulsáveis ${ }^{[2]}$. Estamos particularmente interessados em entender a influência da atividade muscular local na adaptação microcirculatória ao movimento, um aspeto crítico da recuperação da marcha, o que se entende ser de elevada prioridade para a reabilitação, em algumas formas de AVC. O equilíbrio da dinâmica microvascular é fundamental para entender o impacto da atividade muscular na perfusão do membro inferior, e vários estudos sugerem que a flexão plantar concêntrica muda o fluxo sanguíneo local ${ }^{[3]}$. No entanto, alterações relacionadas com a atividade de flexão dorsal, não foram abordadas anteriormente.

A maioria das atividades da vida diária ocorre na posição de pé e envolve a marcha ${ }^{[3-4]}$. Na extremidade dos membros inferiores, os músculos da região posterior da perna desempenham um papel fundamental nas estruturas vasculares locais, devido à pressão externa exercida sobre as paredes dos vasos, onde se inclui a microcirculação ${ }^{[5]}$. Durante a marcha, ocorre uma alternância regular entre a flexão plantar e a contração dos flexores dorsais, o que se reflete nos ciclos de contração dos músculos antagonistas. Durante a dorsi-flexão, há uma grande diminuição na atividade dos flexores plantares (considerada a principal bomba muscular da perna) ${ }^{[3,5]}$. Além disso, a força necessária para realizar a flexão plantar é maior do que para a flexão plantar, uma vez que requer a capacidade de elevar maior peso do corpo contra a gravidade.

A fraqueza do membro inferior está associada à imobilidade ou estase e estas estão relacionadas com algumas lesões cutâneas, dor muscular e claudicação intermitente, devido a doença de circulação periférica ${ }^{[6-7]}$. O impacto gerado pelos antagonistas da principal bomba muscular da perna na microcirculação permanece pouco esclarecido, especialmente na posição de pé.

Neste estudo, desenvolvemos uma metodologia para avaliar a microcirculação in vivo, na posição ortostática durante a flexão dorsal, utilizando a FPG e a FLD. 


\section{Material and Methods}

Six healthy subjects ( $31 \pm 9$ years old) of both sexes (three women and three male) participated in this study after informed written consent. All procedures fully complied with the principles of the Helsinki Declaration and following amendments ${ }^{[8]}$. The experimental protocol was designed to study the impact of isometric dorsiflexion in the standing position. After stabilizing for 10 minutes sitting up straight, subjects stood 5 minutes with both feet parallel to each other and hands on a table for postural support (Phase I). They were then asked to maintain an active isometric dorsiflexion of both feet for 1 minute with minimum oscillation (Phase II) before returning to the standing phase to recovery for 5 minutes (Phase III). All measurements were taken under controlled conditions, including room temperature $\left(25 \pm 1^{\circ} \mathrm{C}\right)$ and humidity $(40-60 \%)$.

Perfusion changes were assessed with two reflexion PPG sensors (Blood Volume Pulse sensors, PLUX Biosignals, Portugal) connected to a BITalino Plugged microprocessor board (PLUX Biosignals, Portugal) and placed along the medial longitudinal arch of each foot, approximately $2 \mathrm{~cm}$ distal to the first metatarsalphalangeal joint and fixed with a double-sided adhesive strip to minimize probe-tissue movement artifacts. Two LDF probes (457 small angled, Perimed, Sweden) were also used, and placed $1 \mathrm{~cm}$ proximal from the PPG probe, fixed with a double-sided adhesive tape (PF 1053 , Perimed, Sweden). The influence of the ambient light on the PPG recording was minimized by covering the sensor with an opaque adhesive tape. Skin temperature was also registered by the LDF system. PPG and LDF signals were collected at 100 and $32 \mathrm{~Hz}$ sampling rates, respectively. Skin blood flow was calculated as the mean waveform amplitude for the PPG signals, and as the mean amplitude of the LDF signals, both expressed in arbitrary units (AU). Pulse Rate (PR) was obtained from the PPG signal and calculated as the number of waveforms per minute (/min). Blood flow and PR means were calculated every minute in each phase. Results were expressed as the calculated mean values for both feet. The Wilcoxon signed-rank test was used for phase comparisons, and a $\mathrm{p}<0.05$ value for significance was adopted.

\section{Material e Métodos}

Seis indivíduos saudáveis ( $31 \pm 9$ anos), ambos os gêneros (três mulheres e três homens) participaram neste estudo após terem dado conhecimento por escrito. Todos os procedimentos respeitaram plenamente os princípios da Declaração de Helsinky segundo os seus princípios ${ }^{[7]}$. O protocolo experimental foi projetado para estudar o impacto da flexão dorsal isométrica na posição de pé. Depois de ambientação por 10 minutos sentados direitos, os sujeitos ficaram na posição de pé durante 5 minutos com os pés colocados paralelos entre si, e as mãos sobre uma mesa para suporte postural (fase I), posteriormente foi solicitado que mantivessem uma flexão dorsal isométrica ativa de ambos os pés por 1 minuto com oscilação mínima (fase II), retornando à posição inicial para recuperação por $5 \mathrm{~min}$ (fase III). Todas as medidas foram realizadas num local com temperatura $\left(25 \pm 1^{\circ} \mathrm{C}\right)$ e condições de humidade (40$60 \%$ ) controladas.

As alterações de perfusão foram avaliadas com dois sensores de reflexão FPG (Sensores de pulso de volume de sangue, PLUX Biosignals, Portugal) conectados a uma placa de microprocessador BITalino Plugged (PLUX Biosignals, Portugal) e colocados ao longo do arco longitudinal medial de cada pé, aproximadamente $2 \mathrm{~cm}$ distalmente à primeira articulação metatarso-falangica, mantidos com uma tira adesiva de dupla face para minimizar o artefato do movimento da sonda-tecido. Foram também utilizadas duas sondas de FLD (457 pequenos ângulos, Perimed, Suécia) colocadas 1 $\mathrm{cm}$ proximalmente da sonda FPG e fixadas com uma fita adesiva de lado duplo (PF 105-3, Perimed, Suécia). A influência da luz ambiente na gravação FPG foi minimizada cobrindo o sensor com uma fita adesiva opaca. A temperatura da pele foi registrada pelo sistema FLD. Os sinais FPG e FLD foram coletados a uma taxa de amostragem de $100 \mathrm{~Hz}$ e $32 \mathrm{~Hz}$, respetivamente. $\mathrm{O}$ fluxo sanguíneo da pele foi calculado pela amplitude da forma de onda média para os sinais FPG, e como a amplitude média dos sinais FLD, ambos expressos em unidades arbitrárias (AU). A frequência de pulso (FP) foi obtida a partir do sinal FPG e calculada como o número de ondas por minuto (/ min). O fluxo sanguíneo e a FP foram calculados a cada minuto em cada fase. Os resultados foram expressos como os valores médios calculados para ambos os pés. O teste Wilcoxon de classificação assinada foi utilizado para comparações de fase, e foi adotado um valor de $\mathrm{p}<0,05$. 


\section{Results and Discussion}

Results are shown in Table 1, and these include values registered from both limbs during the execution of the experimental protocol.

The standing position is one of most frequent postures of our daily life activities, emphasizing the significance of the contraction of muscles bundles to facilitate venous return in lower extremities ${ }^{[12]}$. The return of blood from the extremity to the heart does not exclusively depend on the muscle pump activity, but this mechanism is vital to preserve the integrity of the lower limb microcirculation, because it is able to reduce the pressure of the capillary network initiated by the standing position itself ${ }^{[13]}$. Moreover, standing and walking, are functional tasks of complex muscular activity, involving reciprocity of movements and permanent cycles of contraction/relaxation.

\section{Resultados e Discussão}

Os resultados são apresentados na tabela 1, que também inclui valores registados de ambos os membros, durante a execução do protocolo experimental.

A posição de pé é uma das posturas mais frequentes de nossas atividades da vida diária, enfatizando o significado da contração dos feixes de músculos para facilitar o retorno venoso nas extremidades inferiores ${ }^{[12]}$. O retorno do sangue da extremidade para o coração não depende apenas da atividade da bomba muscular, mas este mecanismo é vital para preservar a integridade da microcirculação do membro inferior, pois é capaz de reduzir a pressão da rede capilar, iniciada por a própria posição ${ }^{[13]}$. Além disso, a marcha, é uma tarefa funcional que requer atividade muscular complexa, envolvendo uma reciprocidade de movimentos e ciclos permanentes de contração / relaxamento.

Table 1 / Tabela 1 - Mean and standard deviation of the parameters calculated for the three phases of the protocol. Mean values results from the measurement from both limbs. Statistical comparison with Phase $1(*-\mathrm{p}<0.05)$

Média e desvio-padrão dos parâmetros calculados para as três fases do protocolo. Os valores médios resultam da média obtida de ambos os membros em medição. Comparação estatística com a Fase I $(*-p<0,05)$

\begin{tabular}{|c|c|c|c|c|c|c|}
\hline & \multicolumn{2}{|c|}{ Phase/Fase I } & \multicolumn{2}{|c|}{ Phase/Fase II } & \multicolumn{2}{|c|}{ Phase/Fase III } \\
\hline & right & left & right & left & right & Left \\
\hline PPG/FPG (AU) & $12.2+2.9$ & $14.0+6.3$ & $6.8+1.6$ & $7.5+1.4$ & $12.0+3.9$ & $12.9+6.6$ \\
\hline$m \pm \underset{p}{m s d} / d p$ & \multicolumn{2}{|c|}{$\begin{array}{c}13.4+3.6 \\
-\end{array}$} & \multicolumn{2}{|c|}{$\begin{array}{c}7.2+1.4 \\
0.028^{*}\end{array}$} & \multicolumn{2}{|c|}{$\begin{array}{c}12.5+5.0 \\
0.463\end{array}$} \\
\hline LDF/FLD (AU) & $6.9+2.5$ & $6.2+1.8$ & $7.9+3.1$ & $8.2+2.2$ & $6.5+2.6$ & $6.4+2.9$ \\
\hline $\begin{array}{c}\mathrm{m} \pm \mathrm{sd} / \mathrm{dp} \\
\mathrm{p}\end{array}$ & \multicolumn{2}{|c|}{$\begin{array}{c}6.5+1.8 \\
-\end{array}$} & \multicolumn{2}{|c|}{$\begin{array}{c}7.9+2.3 \\
0.028^{*}\end{array}$} & \multicolumn{2}{|c|}{$\begin{array}{c}6.4+2.5 \\
0.588\end{array}$} \\
\hline \multicolumn{7}{|l|}{ Pulse rate(/min) } \\
\hline $\mathrm{m} \pm \underset{\mathrm{p}}{\mathrm{sd} / \mathrm{dp}}$ & \multicolumn{2}{|c|}{$\begin{array}{c}67.5+6.6 \\
-\end{array}$} & \multicolumn{2}{|c|}{$\begin{array}{c}70.5+7.0 \\
0.173\end{array}$} & \multicolumn{2}{|c|}{$\begin{array}{c}66.6+6.4 \\
0.293\end{array}$} \\
\hline
\end{tabular}

We examined the impact of the dorsiflexors on the microcirculation, studying the peripheral microvascular response to isometric muscle activity in the orthostatic position using two different technologies, PPG and LDF. Skin temperature was similar for all volunteers $\left(28.33 \pm 1.4^{\circ} \mathrm{C}\right)$ during the protocol (Figure 1). Comparing Phase II and Phases I and III, statistically significant differences between right and left limbs perfusions could not be found ( $p>0.05)$. The isometric position maintained by the dorsiflexors, although very unstable, did not affect recordings during Phase II.

Our results have shown that, under these conditions, dorsiflexion (Phase II) changes perfusion in opposite ways (Figure 2 and Figure 3 ). In fact, perfusion changes decreased significantly with PPG $(p=0.028)$ while they
Examinámos o impacto dos flexores dorsais na microcirculação, estudando a resposta microvascular periférica à atividade muscular isométrica na posição ortostática usando duas tecnologias diferentes FPG e FLD. A temperatura da pele foi semelhante para todos os voluntários $\left(28,33 \pm 1,4^{\circ} \mathrm{C}\right)$ durante a execução do protocolo (Figura 1).

Não foram encontradas diferenças estatisticamente significativas entre a perfusão dos membros direito e esquerdo, comparando a fase II e as fases I e III ( $p>$ $0,05)$. A posição isométrica mantida pelos flexores dorsais, embora por vezes instável, não afetou os registos durante a fase II.

Os resultados mostraram que, nestas condições em que foi executado o protocolo, a flexão dorsal (fase II) al- 


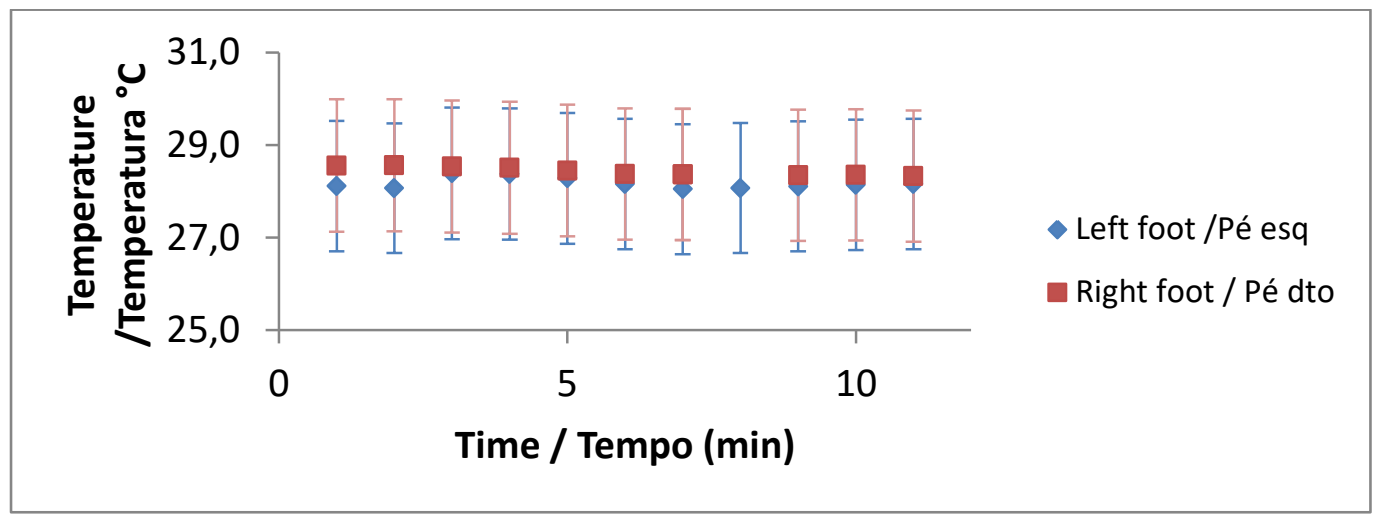

Figure 1 / Figura 1 - Skin temperature $( \pm s d)$ during the protocol for both feet

Temperatura da pele $(+\mathrm{dp})$ em ambos os pés, durante o protocolo experimental

increased significantly with LDF $(\mathrm{p}=0.028)$ (Table 1$)$. These results are in line with previous findings that suggest that these differences might be related to the depth of measurement for each technique, ${ }^{[9]}$ as PPG seems to measure in deeper regions than LDF ${ }^{[10]}$. Skin has a very compliant circulation and, in presence of a mechanism that causes variations in blood flow, the response may be different according to the microvascular networks where the signal is recorded ${ }^{[1-12]}$. The peripheral displacement of the local blood volume could explain this behaviour, contributing to change blood flow oscillation similar to the calf muscle contraction ${ }^{[13-15]}$. In fact, the present study shows that the effect of dorsiflexion over local microcirculation is very similar to that of plantar flexion. This similarity may be explained by the close connections of dorsiflexion with the eccentric contraction of the plantar flexors in the calf and with ankle joint pump ${ }^{[16-17]}$ suggesting that even in the presence of calf muscle weakness, variations in microcirculation may occur by the activity of antagonistic muscles. Since the effect of dorsiflexors during a lack of gastrocnemius activity causes significant differences in distal lower limb perfusion, further studies are necessary to assess its importance as a muscular pump in the return circulation.

\section{Conclusion}

The proposed methodology allowed the in vivo evaluation of microcirculatory adaptation to movement in the orthostatic position. tera a perfusão de forma diferente para a FPG e para a FLD (Figura 2 e Figura 3). De fato, as alterações de perfusão diminuíram significativamente com FPG ( $\mathrm{p}=$ $0,028)$, enquanto aumentaram significativamente com FLD $(p=0,028)$ (tabela 1). Estes resultados estão em linha com achados anteriores que sugerem que essas diferenças podem estar relacionadas com a profundidade de medida para cada técnica ${ }^{[9]}$, onde FPG parece medir em regiões mais profundas do que FLD ${ }^{[10]}$. A pele tem uma circulação muito complacente e, na presença de um mecanismo que causa variações no fluxo sanguíneo, a resposta pode ser diferente de acordo com as redes microvasculares onde o sinal é gravado ${ }^{[11-12]}$. O deslocamento periférico do volume sanguíneo local poderia explicar este comportamento que contribui para uma oscilação do fluxo sanguíneo, semelhante à contração muscular da região posterior da perna ${ }^{[13-15]}$. De fato, o presente estudo mostra que o efeito da flexão dorsal sobre a microcirculação local é muito semelhante ao da flexão plantar. Esta situação pode ser explicada pela ligação que a flexão dorsal tem com a contração excêntrica dos flexores plantaras e à bomba situada na articulação do tornozelo [16-17], sugerindo que mesmo com fraqueza muscular do dos flexores plantares, as variações na microcirculação podem ocorrer pela atividade de seus músculos antagonistas. Uma vez que o efeito dos flexores dorsais durante a baixa atividade dos flexores plantares provoca diferenças significativas na perfusão distal do membro inferior, estudos futuros são necessários para avaliar a sua importância como bomba muscular na circulação de retorno.

\section{Conclusão}

O protocolo experimental proposto neste estudo, permitiu analisar a reatividade da microcirculação a nível da pele com a atividade da flexão dorsal, na posição ortostática. 




Figure 2 / Figura 2 - Time evolution of the mean $\left({ }_{\mathrm{s}} \mathrm{d}\right) \mathrm{PPG}$ signals throughout the experimental protocol

Evolução temporal dos sinais médios $( \pm$ Sd $)$ de FPG ao longo do protocolo experimental

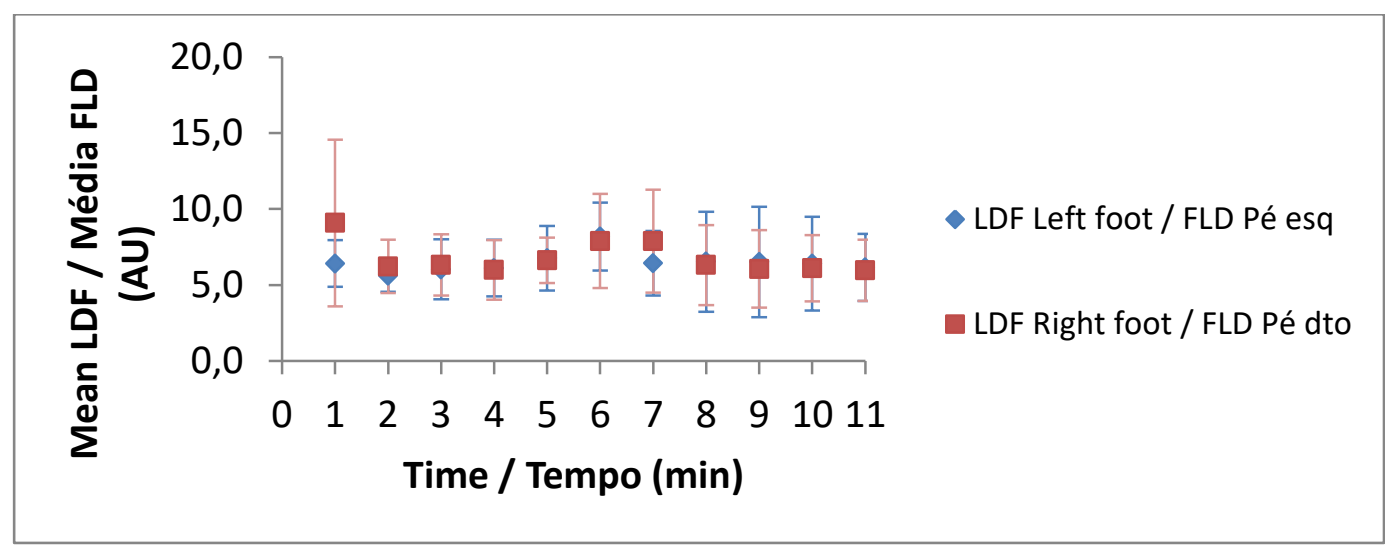

Figure 3 / Figura 3 - Time evolution of the mean $( \pm \mathrm{sd})$ LDF signals throughout the experimental protocol

Evolução temporal dos sinais médios $( \pm$ sd) de FLD ao longo do protocolo experimental

\section{Acknowledgements}

The authors would to express our thanks to the participants.

This work was supported by national funds from FCT Fundação para a Ciência e a Tecnologia, I.P, within the project UID/DTP/04567/2016

\section{Conflict of interests}

The authors declare that there are no financial and/or personal relationships that could be viewed as presenting a potential conflict of interests.

\section{Agradecimentos}

Os autores agradecem a colaboração dos participantes no estudo

Este trabalho é apoiado por fundos nacionais através da FCT - Fundação para a Ciência e a Tecnologia, I.P., no âmbito do projeto UID/ DTP/04567/2016

\section{Conflito de Interesses}

O autor declara não existir qualquer relação pessoal ou financeira que possa ser entendida como um potencial conflito de interesses. 


\section{References/ Referências}

[1] Recek C. Calf pump activity influencing venous hemodynamics in the lower extremity. Int J Angiol. 2013; 22(1):23-30.

[2] Allen J. Photoplethysmogrphy and it application in clinical physiological measurement. Physiological Measurement. 2007 epub Mar;28(3):R1-39..

[3] Caldwell J, Wardlow G, Branch P, Ramos M, Black C, Ade C. Effect of exercise-induced muscle damage on vascular function and skeletal muscle microvascular deoxygenation. Physiol Reports, 2016, 4 (22), e13032.

[4] Pries A, Secomb T. Modeling structural adaptation of microcirculation. Microcirculation. 2008; 15(8): 753-764. DOI:10.1080/10739680802229076

[5] Keijsers J, Leguy C, Huberts W, Narracott A, Rittweger J, van de Vosse F. A 1D pulse wave propagation model of the hemodynamics of calf muscle pump function. isE: Int. J. Numer. Meth. Biomed. Engng. (2015); e02714

[6] Tokizawa K, Mizuno M, Muraoka I. Forearm vascular responses to combined muscle metaboreceptor activation in the upper and lower limbs in humans Exp Physiol 2006: 91.4 pp 723-729

[7] Hamburg N, Creager M. Pathophysiology of Intermittent Claudication in Peripheral Artery Disease. Circ J 2017; 81: 281 - 289

[8] World Medical Association Declaration of Helsinki Ethical Principles for Medical Research Involving Human Subjects. JAMA. 2013;310(20):2191-2194

[9] Silva H, Bento M, Vieira H, Monteiro Rodrigues L. Comparing the spectral components of laser Doppler flowmetry and photoplethysmography signals for the assessment of the vascular response to hyperoxia Biomed Biopharm Res, 2017; (14) 2:187-194 DOI: 10.19277/bbr.14.2.161

[10] Budidha K, Abay TY, Kyriacou PA. Investigation of Photoplethysmography, Laser Doppler Flowmetry and Near Infrared Spectroscopy during induced thermal stress Conf Proc IEEE Eng Med Biol Soc. 2015;2015:6417-20.

[11] Webb et al. Epidermal devices for noninvasive, precise, and continuous mapping of macrovascular and microvascular blood flow. Sci. Adv. 2015;1:e1500701

[12] Tran B, Chiu A, Tran C, Rogacion D, Tfaye N, Ganesan G, Galassetti P.s Epexpercise and Repeated Testing Improves Accuracy of Laser Doppler Assessment of Microvascular Function Following Shortened (1-min) Blood Flow Occlusion, Microcirculation. 2016 May; 23(4): $293-300$.

[13] Jacob M, Chappell D, Becker BF. Regulation of blood flow and volume exchange across the microcirculation. Critical Care (London). 2016 Oct 21;20(1):319.

[14] Charkouondian N. Mechanisms and modifiers of reflex induced cutaneous vasodilation and vasoconstriction in humans. J Appl Physiol (1985) 2010 Oct; 109(4): 1221-1228.

[15] Bazigou E, Makinen T. Flow control in our vessels: vascular valves make sure there is no way back. Cell. Mol. Life Sci. 2013; 70:1055-1066 is

[16] Tanno J, Gatate Y, Kasai T, Nakano S, Senbonmatsu T, Sato O, et al. A Novel Index Using Ankle Hemodynamic Parameters to Assess the Severity of Peripheral Arterial Disease: A Pilot Study. PLoS ONE, 2016. 11(10): e0164756. doi:10.1371/journal.pone.0164756

[17] Jurczak I, Kowalski J, Irzmanski R. Impact of cardiac rehabilitation on peripheral circulation as assessed by impedance plethysmography: a randomized clinical trial. Eur J Phys Rehabil Med 2014, 50:609-16 